\title{
Histopathology of liver and gill of C.gariepinus- (Burchell 1822) with swollen abdomen following exposure to acute and sublethal concentrations of chlorpyrifos-ethyl
}

\author{
*Ogueji ${ }^{1}$, Emmanuel. Okechukwu, Ibrahim Baba.Usman ${ }^{2}$ and Auta, Jehu ${ }^{3}$ \\ ${ }^{1}$ Department of Biology/Microbiology/Biotechnology, Federal University, Ndufu-Alike, Ikwo, P.M.B 1010, Abakaliki, Ebonyi State, \\ Nigeria \\ ${ }^{2}$ Department of Biological Sciences, Faculty of Natural Sciences, Ibrahim Badamasi Babangida University Lapai, Niger State, \\ Nigeria \\ ${ }^{3}$ Department of Biological Science Ahmadu Bello University, Zaria Nigeria. \\ *Corresponding author E-mail: oguejiokey@yahoo.com
}

\begin{abstract}
Chlorpyrifos-ethyl, an organophosphate insecticide, was evaluated for its histopathological effects on African catfish Clarias gariepinus, by light microscopy. Juveniles were exposed to acute $(0.64 \mathrm{mg} / 1,0.80 \mathrm{mg} / 1,0.96 \mathrm{mg} / 1,1.12 \mathrm{mg} / \mathrm{l}$, $1.28 \mathrm{mg} / \mathrm{l}$, and a control) and sublethal $(0.045 \mathrm{mg} / 1,0.096 \mathrm{mg} / \mathrm{l}$ and $0.192 \mathrm{mg} / \mathrm{l}$ and control) concentrations of chlorpyrifos-ethyl for a duration of $96 \mathrm{hrs}$ and 8 weeks respectively. The gills and liver samples of control and treated fish with swollen abdomen were removed at the end of 96hrs and 8 weeks durations of exposure for histological examinations. No degenerations were observed in the control samples. The highest acute and sub-lethal doses of the toxicant induced occasionally on the fish, morphological degeneration characterized by swollen abdomen. The histopathological degenerations in the gill was characterized as mucous cell secretion in the gill, lamella hyperplasia/hypertrophy, oedema, occlusion of inter-lamella spaces; Degenerations in the liver included: enlargement of sinusoids, massive infiltration of sinusoidal spaces and central vein by mono and polymorphonuclear leukocytes and RBC's, pyknotic nuclei and coagulation necrosis. Fish health was negatively affected.
\end{abstract}

Keywords: Chlorpyrifos-ethyl, Clarias gariepinus, Histopathology, Gill, liver.

\section{Introduction}

Insecticides have been reported to contaminate not only surface water, but ground water, rainwater and fog water all of which lead to the insecticides being transported long distances across national and regional boundaries [13]. Due to rapid volatilization property of many insecticides, they have the tendency to pollute air around areas of application [26], and can travel by air to sites further away from the site of application. Direct and indirect contamination of aquatic environment by pesticides may cause fish kills, reduce fish productivity and elevate concentrations of undesirable chemicals in edible fish tissues. Chlorpyrifos is effective against a wide range of arthropods and insect pests including Coleoptera, Diptera, Homoptera and Lepidoptera species. Chlorpyrifos is directly toxic to the nervous system and is also transformed inside animals to chlorpyrifos-oxon and 3, 5, 6-trichloro-2-pyridinol (TCP) both of which are many times more toxic to the nervous system than chlorpyrifos itself [4]. Due to its lipophilic nature, fish are able to absorb and bioconcentrate chlorpyrifos to moderate or high levels and variable bioconcentration factors (BCF) between 1005100 have been reported [26]. They enter water bodies through intentional application, run-off from farms, aerial drift and accidental and illegal release [33]. In 2000, there were 164 registered products containing Chlorpyrifos [20]. In addition, organophosphates are reactive and may cause damage through direct oxidative damage to membranes [12]. In Nigeria, Government regulation of the use of pesticides is contained in the "Guidelines and standards for environmental pollution control in Nigeria" by FEPA, now Ministry of Environment. In the document, the limit of less than $0.01 \mathrm{mg} / \mathrm{l}$ applies to all types and classes of pesticides [10]. This implies that there is lack of adequate baseline information on the toxicity of many pesticides to fish species. Many insecticides degrade into a variety of compounds (metabolites) in the air, water, soil, plants and animals. Most of them are more toxic than the parent compound, and adversely affect other living things than the pest they are designed to kill. Effects on non-target organisms include acute and chronic hazards [3]. 
Environmental monitoring of pesticides can be for the purpose of generating baseline information, assessing the effects of pesticides to the environment and or continuous measurement of environmental load to ensure that regulatory requirements and standards are being met [7]. Oxidative stress occurs when ROS overwhelm the cellular defenses and damage proteins, membranes and DNA and their production may be enhanced by xenobiotics[14]. Reactive oxygen species are removed by cellular defenses such as GPx, superoxide dismutase, catalase (CAT), reduced glutathione (GSH), Vitamin E, and carotenoids [14]. However, when ROS becomes too numerous, damage to membranes, proteins and DNA results. This study focused on gills and liver because gills are the main target for many aquatic pollutants and liver is the site for detoxification of xenobiotics. It is of great importance to evaluate the effects of pollution on fish both for environmental protection and for socioeconomic reasons [16]. Clarias gariepinus, an ominivore freshwater fish is a popular delicacy relished throughout tropical Africa. It is a prominent culture species because of its hardiness and fast growth [23]. C.gariepinus is a bottom dweller and is therefore at a very high risk of chlorpyrifos-ethyl intoxication than pelagic species.

\section{Materials and methods}

\section{1 experimental fish}

Healthy Clarias gariepinus juveniles (average weight $16.35 \pm 1.25 \mathrm{~g}$ and standard length $10.5 \pm 0.05 \mathrm{~cm}$ ) were obtained from Kubani Dam Ahmadu Bello University, Zaria. The fish were conveyed to fisheries laboratory in a portable wellaerated white polythene bag containing water from the Dam. They were held in large water baths of 160L capacity at $24.5-25.5^{\circ} \mathrm{C}$ and acclimatized for two weeks in de-chlorinated municipal water. A total of 180 specimens were randomly assigned to give a loading of 10 fish per tank to avoid overcrowding. During this period, the fishes were fed with pelleted diet containing $35 \%$ crude protein twice per day at $5 \%$ body weight. Also, the water in the glass aquaria was changed once every two days. The fishes were accepted as well adapted to laboratory conditions when less than $5 \%$ death was recorded for the 14 days period and feeding was discontinued 24 hours before the start of the experimental run [27].

\subsection{Acute bioassay}

Acute 96-h static bioassays were conducted in the laboratory following the methods of [28] and [1]. The acute concentrations for chlorpyrifos-ethyl were $0.64 \mathrm{mg} / 1,0.80 \mathrm{mg} / 1,0.96 \mathrm{mg} / 1,1.12 \mathrm{mg} / 1,1.28 \mathrm{mg} / \mathrm{l}$, and a control with no toxicant. Each concentration was replicated three times. The desired stock solution was measured and introduced into $25 \mathrm{~L}$ of de-chlorinated tap water in the glass aquaria. The mixture was allowed to stand for 30 minutes before introducing test fishes. Survival and mortality were recorded from 1 to 6, 8, 16, 24, 72 and 96 hours. Fishes were considered dead when the opercular movement ceased and there was no response to gentle probing. Fish with swollen abdomen were sampled at the end of 96hrs duration of exposure.

\subsection{Sub-lethal bioassay}

Based on the result of $96-\mathrm{h} \mathrm{LC}_{50}$, which was estimated to be $0.92 \mathrm{mg} / \mathrm{l}$, the sub-lethal concentrations was determined using 1/5, 1/10 and 1/20 ratios as recommended by [22]. The juveniles were exposed to sublethal concentrations of Chlorpyrifos-ethyl for 8 weeks. The concentrations used for chronic study were $0.045 \mathrm{mg} / \mathrm{l}, 0.096 \mathrm{mg} / \mathrm{l}$, and $0.192 \mathrm{mg} / \mathrm{l}$ and control (0.00) with no toxicant. Each treatment was in triplicate. With the exception of the control tanks, appropriate volumes of the toxicant were added into each tank. The fishes were randomly assigned to give a loading of 10 fish per tank. Fishes were fed to $3 \%$ body weight and with $35 \%$ crude protein level pelleted diet. To avoid variation in chlorpyrifos-ethyl concentration, test solutions were changed every $12 \mathrm{hrs}$. Biodegradation occurring in this period of time is less than $10 \%$ of the initial concentration [11].This helps to maintain toxicant strength and the level of dissolved oxygen, as well as minimizing the level of ammonia during the experiment. Fish with swollen abdomen were sampled at the end of 8 weeks.

\subsection{Histological procedures}

Fish with swollen abdomen were killed and their gills and liver tissues extracted by dissecting the fish, and they were preserved in 10\% formalin [29]. They were washed and dehydrated progressively in increasing percentages of alcohol (30, 50, and 70, 90 and absolute). For infiltration, mixture of alcohol and chloroform in varying volumes were used in this ratio 3:1, 1:1, 1:3 and absolute chloroform. Tissue was embedded in semi synthetic paraffin wax with a mean fusion point of $54-56^{\circ} \mathrm{C}$. Sections were cut at $5 \mu \mathrm{m}$. Harris's hematoxylin and acetic eosin were employed as general stains at 
the Ahmadu Bello University Teaching Hospital (ABUTH'S) Histopathology Department. All the slides were examined under light microscope (Nikon TE3000) and photomicrographs were taken at $\mathrm{x} 10$, x20, or $\mathrm{x} 40$ with a digital camera (Nikon 9000) at its highest resolution $(3.3 \mathrm{mb})$. Photomicrographs of the various sections showing the effects of chlorpyrifos-ethyl on the cell structure of the target organ were made at x200, x300 and x400 magnifications.

\section{Results}

\subsection{Histology of normal (control) C. gariepinus gills and liver}

Light microscopic examination of photomicrograph of the vertical section of the control gills (Fig.7) shows two distinct epithelial surfaces, the lamellar and filament epithelia (also termed the secondary (S) and primary (P) epithelia). The outer covering of squamous epithelia forms a continuous lining. The filament/ primary lamella $(\mathrm{P})$ is rounded at the apices while the projecting secondary lamellas (S) are clearly interspaced. C.gariepinus from the control had normal gill morphology (Fig.7) relative to proliferative (increase in cell numbers), inflammatory (infiltration of mono and polymophonuclear leukocytes), structural (modified tissue or cellular architecture), cytoplasmic (altered cellular volume or presence of storage products) and degenerative (general necrosis) alterations of fish exposed to sub-lethal concentrations of chlorpyrifos-ethyl. Each gill is made up of filaments or primary lamellae arranged in double rows along the bone. Secondary gill lamellae originate from the filaments and are disposed perpendicular to the inferior and superior margins of each filament. The filaments serve more for support of the secondary lamellae than for respiration. Each secondary lamella contains a thin-walled gill sinusoid that allows for the continuous exchange of respiratory gases such as oxygen and soluble metabolic wastes such as carbon dioxide and ammonia. In addition the respiratory epithelium of the secondary lamellae contains specialized chloride cells that assist with osmoregulation by excreting chloride, potassium and sodium ions.

The photomicrograph of the control liver parenchyma had the pattern of teleost fish, in which polygonal cells, similar to liver cells, were arranged in irregular cell cords separated by sinusoids. The sinusoids are thin strip with sparse connective tissue. They make continuous communication and finally converge into the central vein (Fig.5). The nucleus and nucleoli of the control are not as prominent and enlarged as in the treated fish.

The highest acute and sublethal doses of the toxicant induced occasionally on the fish, morphological degeneration characterized by swollen abdomen. The histopathological structural, proliferative and degenerative changes in the gill was characterized as oedema, occlusion of interlamella spaces, lamella hyperplasia, mucous cell secretion in the gill; Structural, inflammatory and degenerative changes in the liver included: enlargement of sinusoids, massive infiltration of sinusoidal spaces and central vein by mono and polymorphonuclear leukocytes and RBC's, pyknotic nuclei and coagulation necrosis.

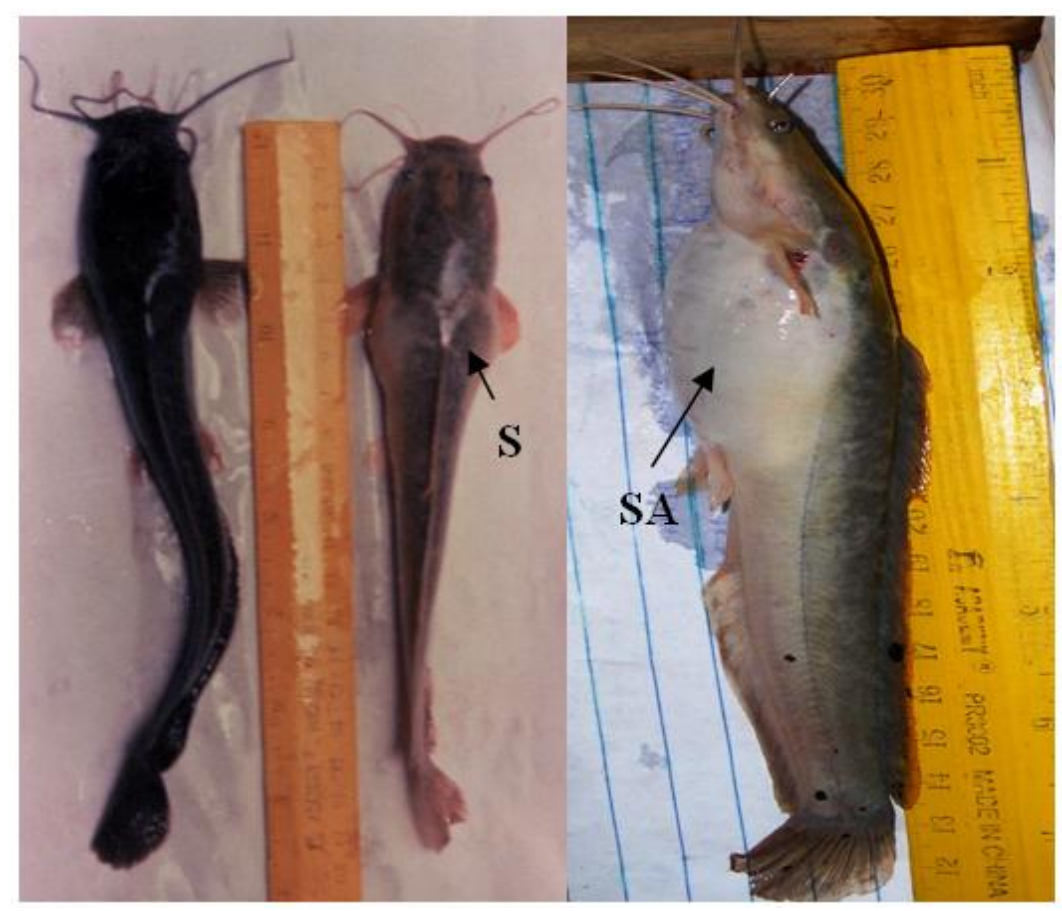

Fig.1 \& 2: Normal and fish with Swollen Abdomen in Chlorpyrifos-ethyl treated fish 


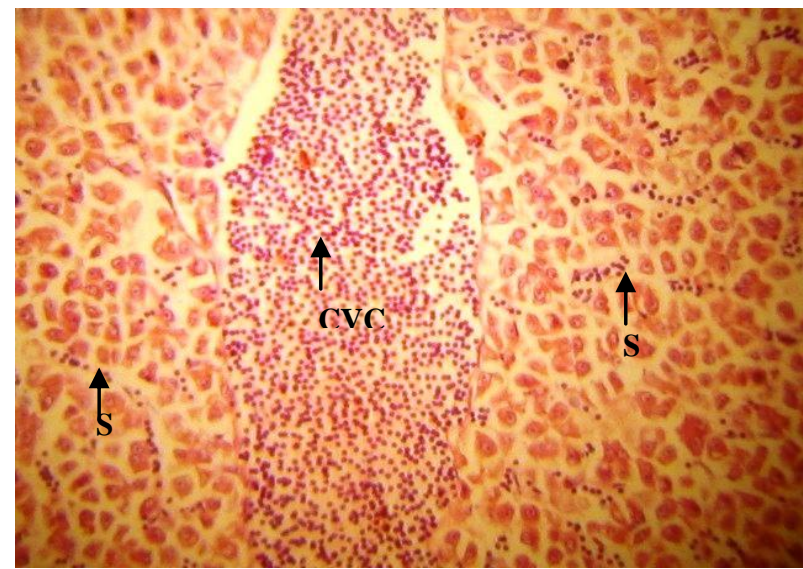

Fig.3: The photomicrograph of fish with swollen abdomen shows some inflammatory cells (lymphocytes and macrophages) infiltration of the periportal region, Congested central vein (CCV), Sinusoids (S) contained RBCs and inflammatory cells. After $96 \mathrm{hr}$ exposure to $1.28 \mathrm{mgl}^{-1}$ chlorpyrifos-ethyl. H and E stain x200

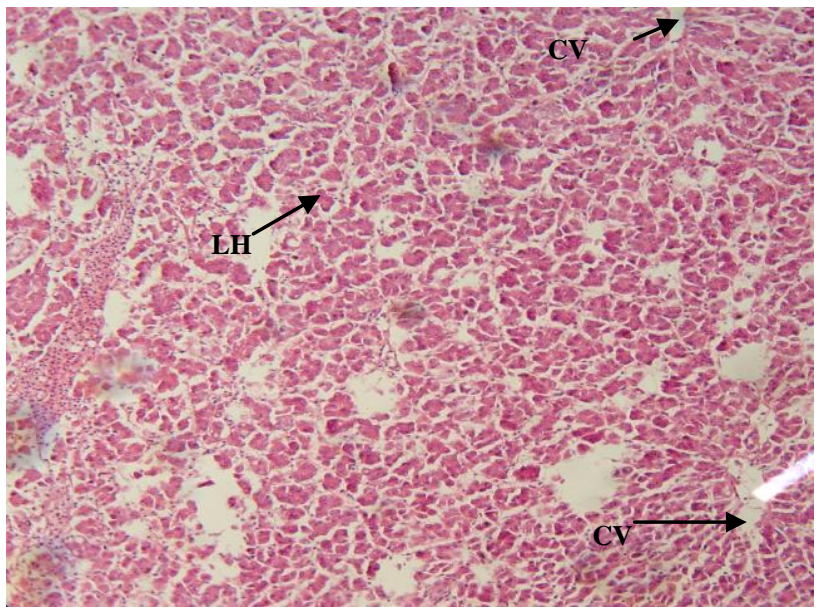

Fig.5: The photomicrographs of Normal Liver architecture of C.gariepinus (Control), note the Liver hepatocytes (LH) and Central vein (CV). H \& E Stain. X200.
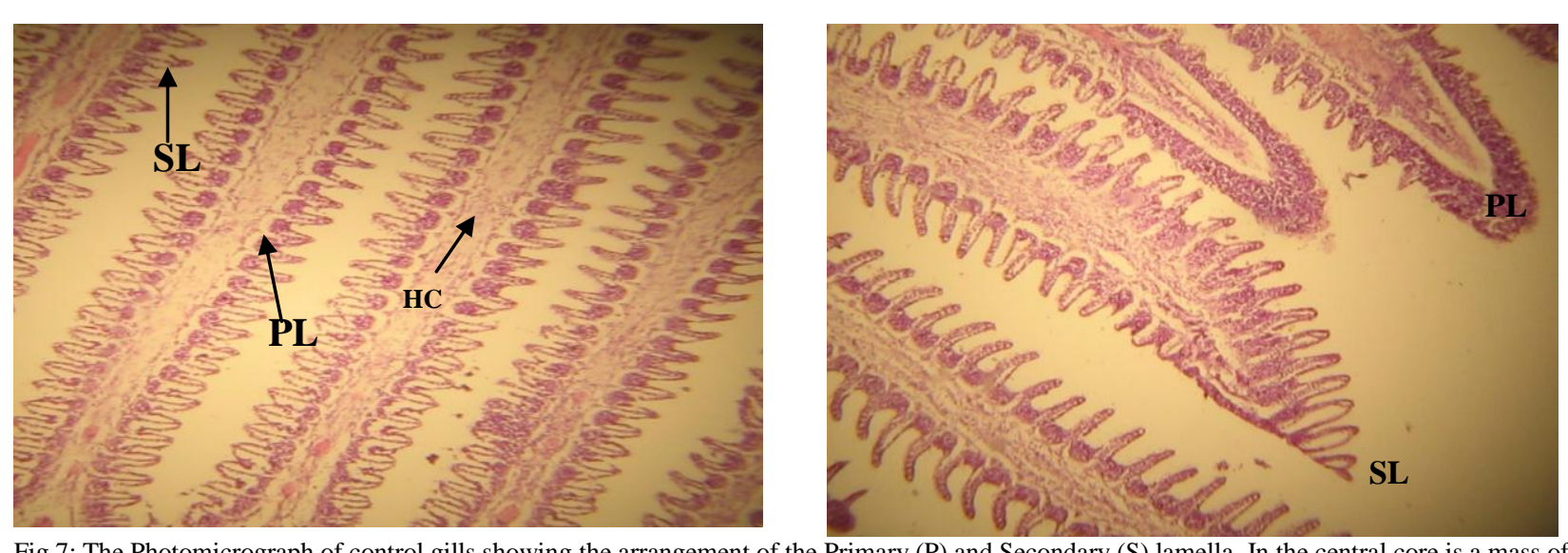

Fig.7: The Photomicrograph of control gills showing the arrangement of the Primary (P) and Secondary (S) lamella. In the central core is a mass of hyaline cartilage (HC). H \& E Stain. X400.

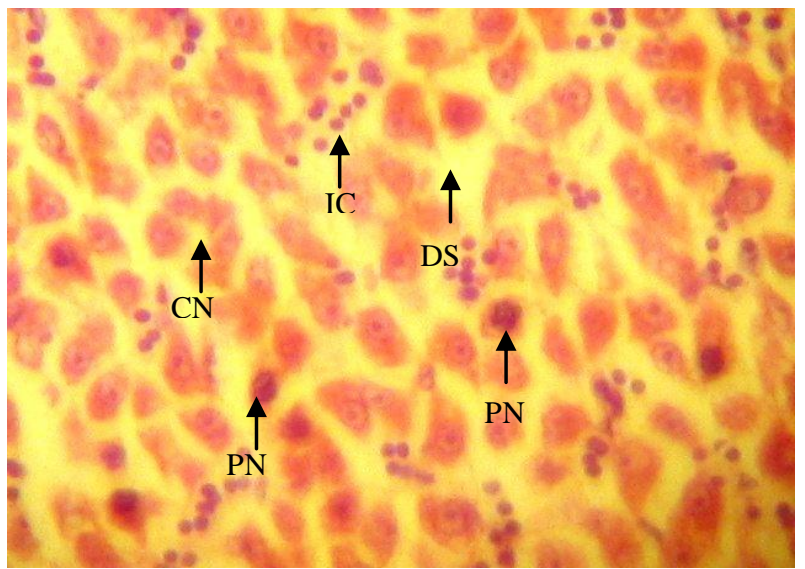

Fig.4: The photomicrograph shows inflammatory cells (lymphocytes and macrophages) infiltration of the periportal region (IC), Coagulation necrosis (CN), pyknotic nuclei (PN) Dilated sinusoidal spaces (DS), Massive infiltration of sinusoidal spaces by inflammatory cells (IC) After 4 weeks duration of exposure to $0.192 \mathrm{mgl}^{-1}$ chlorpyrifos-ethyl. $\mathrm{H}$ \& E stain $\mathrm{x} 300$.

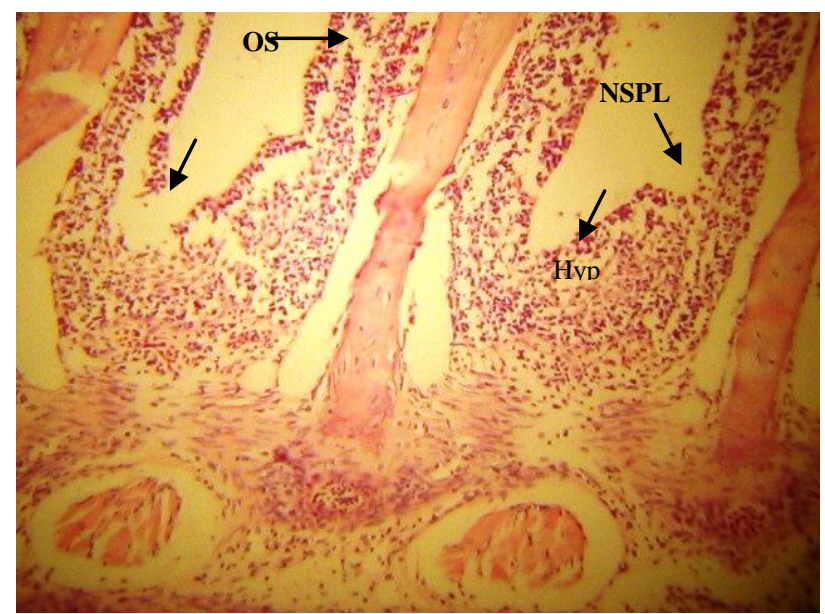

Fig.6: The photomicrograph shows the degenerative changes in the gill tissue of fish with swollen abdomen. Gill structure with lamella edema (LE), hyperplasia (Hyp), necrosis of the primary \& secondary respiratory cells (NSPL), Occlusion of secondary inter-lamella spaces (OS). After 4 weeks exposure to $0.192 \mathrm{mgl}^{-1}$ chlorpyrifos-ethyl. $\mathrm{H} \& \mathrm{E}$ stain $\mathrm{x} 400$ 


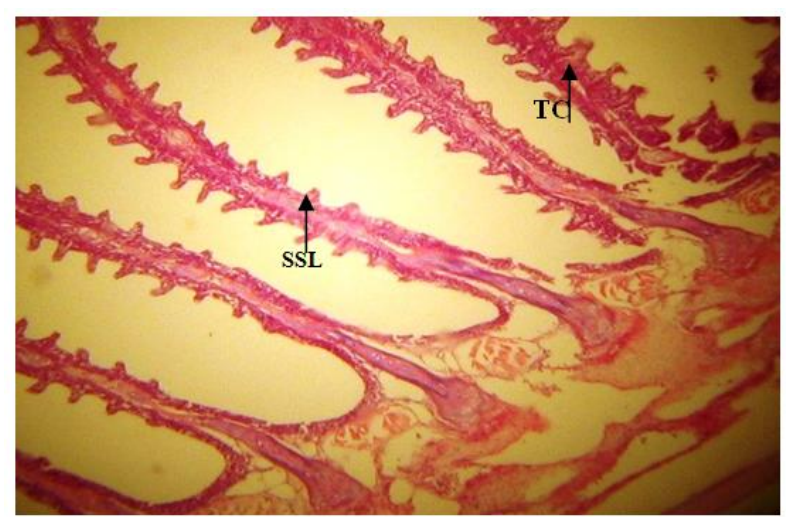

Fig.8: Photomicrograph of gills showing shrinkage of secondary lamella (SSL), thin core (TC), and shrinkage of cartilaginous supporting mass resulting in decrease in size of gills. After $96 \mathrm{hrs}$ exposure to $1.12 \mathrm{mgl}^{-1}$ acute concentration of chlorpyrifos-ethyl. H \& E Stain. X400

\section{Discussions}

Acute toxicity of chlorpyrifos-ethyl on C.gariepinus was also carried out by static bioassay method, and the result revealed that the insecticide was highly toxic to $C$. gariepinus with $96-\mathrm{h} \mathrm{LC}_{50}$ value of $0.92 \mathrm{mg} / \mathrm{L}$ and NOEC estimated as $0.0092 \mathrm{mg} / \mathrm{L}$. This result is consistent with the findings of several other workers. [9] reported the 96-hour $\mathrm{LC}_{50}$ for chlorpyrifos as $0.009 \mathrm{mg} / \mathrm{L}$ in mature rainbow trout, $0.098 \mathrm{mg} / \mathrm{L}$ in lake trout, $0.806 \mathrm{mg} / \mathrm{L}$ in goldfish, $0.01 \mathrm{mg} / \mathrm{L}$ in bluegill and $0.331 \mathrm{mg} / \mathrm{L}$ in fathead minnow. Chronic exposures of aquatic organisms generally results in no-observable effect concentrations (NOEC's) of $<1.0 \mu \mathrm{g} / \mathrm{L}$. Rainbow trout studies reported a NOEC of $0.5 \mu \mathrm{g} / \mathrm{L}$, while there was complete mortality at $2-3 \mu \mathrm{g} / \mathrm{L}[30]$. Acute $\mathrm{LC}_{50}$ values for freshwater and marine fish have been from 2-520 $\mu \mathrm{g} / \mathrm{L}$, but generally below $100 \mu \mathrm{g} / \mathrm{L}[20]$.

Histopathology is a higher-level response, reflecting prior alteration in physiological and/or biochemical function. The early fusion of secondary lamellae due proliferation of mucous and epithelial cells and was considered a defense response to insecticide exposure rather than a direct effect of the toxicants. This is because mucous cells contain mucins, polyanions composed of glycoproteins that can be effective in trapping toxicants and aid in the prevention of toxicant entry into the gill epithelium [25]. However with prolonged sublethal duration of exposure (4 weeks) to the toxicant, hyperplasia, hypertrophy and rupture of edematous respiratory cells became more pronounced, it became obvious then that the response was more than an adaptive strategy by the fish. It was more as a result of the toxic insult. Although mucous cells may be beneficial in reducing toxicant entry, the inundation of the lamellae by proliferating cells might concurrently impair gas transfer owing to a thickening of the lamellar blood-to-water diffusion barrier and also it is likely to reduce the thickness of the water channels formed by adjacent lamellae, potentially reducing the efficiency of gas exchange and causing hypoxic conditions. The fate of chloride cells in the face of lamellar epithelial hyperplasia was not investigated. However these cells have a central role in osmoregulation, ammonia excretion and acid base balance [5]. Therefore impairment of their function, possibly caused by the proliferation of other cells, may have lead to metabolic upset. The occurrence of swollen abdomen which was restricted to the highest acute and sublethal concentrations may be associated with inhibition of the enzymes carbonic anhydrase and $\mathrm{Na}^{+}-\mathrm{K}^{+}$-ATPase activity in the gill and the intestine of the fish, leading to osmoregulatory/ionoregulatory dysfunction. Both enzymes plays a pivotal role in teleost intestine and gill physiological functions e.g gas exchange, acid-base balance, osmoregulation and clearance of waste products from nitrogenous metabolism [17]. Carbonic anhydrase activities in gill and intestinal homogenates were significantly inhibited by $\mathrm{CdCl}_{2}$ [17]. It is also opined that the chlorpyrifos-ethyl or its breakdown products (chlorpyrifos-oxon) generated excessive reactive oxygen species (ROS), which induced lipid peroxidation in the lining of the intestine, gill and in the liver hepatocytes leading to oxidative stress. This led to loss of membrane integrity and subsequent leakage of fluid into the stomach and enzymes into blood. This also suggests that the insecticides exerted an effect similar to the production of acute and/or haemolytic anaemia in this fish. Gill damage led to reduced oxygen uptake leading to reduced oxygen transport by the erythrocytes. This could lead to inefficient utilization of assimilated food or inhibition of certain enzymes of the metabolic pathways. Our findings are consistent with that of several other authors [24];[32];[17];[12];[23].[19] reported swelling as a result of PCB lesion in the kidney of rainbow trout, and opined that glomerular filtrate may have exerted a deleterious effect on cell membranes resulting in increased permeability and thus allowing fluid to enter the cells. The massive infiltration of mono and polymorphornuclear leukocytes and RBC's, was an evidence of liver inflammation. Recent evidence suggests that waterborne contaminants which generate reactive oxygen species (ROS) may be a significant source of toxicity for aquatic organisms living in polluted environments and may be partially responsible for disruptions in physiological function [18]. In addition, it has been reported that organophosphates are reactive and may cause direct oxidative 
damage to membranes [12]. [21] argued that excessive ROS production in response to xenobiotics inducing compounds can overwhelm endogenous detoxifying mechanisms producing the cumulative damage to cellular constituent's termed oxidative stress.

The cyto-architectural distortions in the gills of C.gariepinus juveniles, observed in the acute exposures, included: fusion of secondary lamella, occlusion of inter-lamella spaces, thin core, and shrinkage of cartilaginous supporting mass resulting in decrease in size of gills. The shrinkage of the lamellae suggests that intake of toxicant occurred via the gills, and the total surface area of the gill has been drastically reduced. The resulting asphyxiation due to insufficient gaseous exchange was probably responsible for the death of some the fingerlings in the course the static and sublethal bioassay study. The shrinkage of the cartilaginous supporting mass implies that there was a collapse of the blood vessels, indicating that the quantity of food and oxygen that reach the cells had reduced considerably thereby impairing the fish health, growth and survival. Respiratory distress is one of the early symptoms of pesticide poisoning, and the gill takes part in metabolism and elimination of xenobiotics [6].

The prevalence of fish with swollen abdomen in the highest acute concentrations implies that, there was high accumulation of this toxicant and its metabolite in the liver of the fish exposed to them. This may be related to the fact that liver plays a key role in accumulation and detoxification of toxicants.

And some of the cyto-architectural distortions included: massive infiltration of mono and polymorphornuclear leukocytes and RBC's, enlargement of sinusoidal spaces, single cell necrosis, focal necrosis and coagulation necrosis. Although natural toxins, such as those produced by viral infections, have been shown to elicit degenerative changes in the liver [2], the simultaneous presence of other tissue alterations can provide increasing evidence that the degenerative changes to the liver are of chemical origin. Observations of inflammatory alterations in the vicinity of necrotic foci suggest that the degenerative changes are more than likely the result of exposure to the chemicals.

[31], reported an increased prevalence of skin pathologies (caudal fin erosion) and proliferative changes (epithelial and chloride cell) to the gills of yellow perch were associated with long-term exposure (3-10 months) to reclaimed sites containing elevated levels of oil sands constituents (Naphthenic acids [NAs] and polycyclic aromatic hydrocarbons [PAHs]). Mucous cells proliferation of yellow perch from oil sands reclaimed environments following longer residency periods has also been observed [31]. The histopathological alterations observed in gills and liver of Corydoras paleatus after exposure to sublethal dose of organophosphate methyl parathion included: epithelial hyperplasia in the respiratory lamellae, edema and detachment of the epithelial cells.

\section{Conclusions and recommendations}

In conclusion, organophosphates (chlorpyrifos-ethyl) are widely used in agriculture in Nigeria. They are increasingly being used in veterinary applications on farm and pet animals, for the protection of stored foodstuffs, for the control of endemics and parasites in public health programmes as well as for household applications in kitchens and bedrooms. Acute exposures of aquatic biota and individuals may result through run-off and adsorption of the insecticides to small dust particles and various other surfaces respectively. The toxicity of this chemical was assessed using morphological and histopathological indices. Fish health was negatively affected. Implications in the wild include: Reduced competitive ability, vulnerability to predation, decreased mating success, decreased energy available for growth, decreased ability to capture food and combat diseases. In the light of the above observations, it is recommended that:

(i) Administrative environmental regulations and legal instruments should be strengthened and adequately enforced with respect to importation and discharge of toxic wastes into the aquatic environment.

(ii) We must use our biomonitoring technology to predict the effects of new chemical substances likely to reach aquatic ecosystems. In addition, we must use our biomonitoring tools to predict the future ecological effects of chemical substances and utilize this knowledge to prevent these substances from reaching hazardous concentrations in the ecosystem.

\section{References}

[1] APHA. American Public Health Association, American Water Works Association (AWWA) and Water Environment Federation (WEF), Standard Methods for the examination of Water and Waste water, 18th Edition; Washington, D.C (1985)

[2] Carls, M.G., Marty, G.D., Meyers, T.R., Thomas, R.E. and Rice, S.D. Expression of viral hemorrhagic septicemia virus in pre-spawning Pacific herring (Clupea pallasi) exposed to weathered crude oil. Canadian Journal of Fisheries and Aquatic Sciences, 55: (1998) 2300-2309.

[3] Caroline, C. Chlorpyrifos, Part1: Toxicology. Journal of Pesticide Reform, 14(4): (1995) 95-20

[4] Chambers, J.E., Forsyth, C.S. and Chamber, H.W. Bioactivation and detoxification of organophosphorus insecticides in rat brains." In Caldwell, J., Hutson D.H., and Paulson. G.D. Intermediary xenobiotic metabolism: Methodology, mechanisms and significance", Basingstoke, U.K: Taylor and Francis. (1989). pp 99-115.

[5] Daoust, P.Y. and Ferguson, H.W. Gill diseases of cultured Salmonids in Ontario. Can. J. Comp. Med. 47: (1983) 358-362. 
[6] Dutta, H.M., Munshi, J.S.D., Roy, P.K., Singh, N.K., Adhikari, S. and Killius, J. Ultrastructural changes in the respiratory lamellae of the catfish, Heteropneustes fossilis, after sublethal exposure to Malathion. Environmental Pollution. 9: (1996) 329-341.

[7] EIA Training Resource Manual. Topic 7: Mitigation and Impact Management. Second Edition. World Bank. (2002) pp78-89

[8] EPA. Pesticide fact sheet: Chlorpyrifos. No. 37. Washington, D.C. (1984).

[9] EXTOXNET. Chlorpyrifos Pesticide Information Profile USDA. (1996)

[10] FEPA. Guidelines and Standards for Environmental Pollution Control in Nigeria. Federal Environmental Protection Agency (FEPA) Nigeria (1991)

[11] Flores, V., Galan, M., and Sales, D. Contaminacion de las agues de la Bahia de Gadiz (IV). Ensayos de biodegradabilidad con dodecilsulfato sodico. Ingenieria Quimica, 131: (1980) 81-111.

[12] Galloway, T.R. and Handy. Immunotoxicity of organophosphorous pesticides. Ecotoxicicology. 12: (2003) $345-363$.

[13] Glotfelty, D.E., J.N. Seiber, L.A. Liljedahl. Pesticides in Fog. Nature 325: (1987) 602-605

[14] Kelly, S.A., Havrilla, C.M., Brady, T.C., Abramo, K.H. and Levin, E.D. Oxidative stress in toxicology: established mammalian and emerging piscine model systems. Environmental Health Perspectives, 106: (1998) 375-384.

[15] Lee, L.E.J., Haberstroh,K., Dixon, D.G., Bols, N.C. Salinity effects on the toxicity of naphthenic acids to rainbow trout cell lines. Can. Technol. Rep. Fish. Aquat. Sci. 91, (2000) 23-31.

[16] Lin, H.C. and Hwang, P.P. Acute and chronic effects of gallium chloride (Gacl3) on tilapia (Oreochromis mossambicus) larvae. Bull. Environ. Contam. Toxicol. 60: (1998) 931-935.

[17] Lionetto, M.G., Giordano, M.E., Villla, S. and Schettino, T. Inhibition of eel enzymatic activities by cadmium. Aquatic Toxicology 48: (2000) $561-571$.

[18] Livingstone, D. Contaminant-stimulated reactive oxygen species production and oxidative damage in aquatic organisms. Marine Pollution Bulletin, 42: (2001) 656-666.

[19] Nestel. H., and Joan Budd. Chronic Oral Exposure of Rainbow Trout (Salmo gairdneri) to a Polychlorinated Biphenyl (Aroclor 1254): Pathological Effects. Canadian Journal of Comparative Medicine. 39: (1975) 28-215.

[20] NRA. Review of chlorpyrifos, National Registration Authority for Agricultural and Veterinary chemicals Canberra, Australia. (2000) pp263.

[21] Oakes, D.K., Mark, E.M. and Glen, J.V. Oxidative stress responses in long nose sucker (Catostomus catostomus) exposed to pulp and paper mill and municipal sewage effluents. Aquatic Toxicology, 67: (2004) 255-271.

[22] Oladimeji, A.A and Ologunmeta, R.T. Toxicity of water-borne lead to Tilapia niloticus. Nig. J. Applied Fish. Hydrobiol. 2: (1987) 19-24.

[23] Olojo, E.A.A., Olurin, K.B., Mbaka, G and Oluwemimo, A.D. Histopathology of the gill and liver tissues of the African catfish Clarias gariepinus exposed to lead. African Journal of Biotechnology 4(1): (2005) 117-122.

[24] Perry S.F. The chloride cell: Structure and function in the gills of freshwater fishes. Annu. Rev. Physiol. 59: (1997) 325-347.

[25] Perry, S.F. and Laurent, P. Environmental effects on fish gill structure and function. In: eds. J.C Rankin, F.B Jesen, Fish Ecophysiology, Chapman and Hall. London: (1993) pp 231-264.

[26] Racke, K.D. Environmental fate of chlorpyrifos. Review of environmental contamination and toxicology 131: (1993) 1-150.

[27] Reish, D.L. and Oshida, P.S. Manual of methods in aquatic environment research Part 10. Short term static bioassay. FAO. fisheries. Technical paper 247, FAO Rome (1987) pp 1- 62.

[28] Spragne, J.B. Measurement of pollution toxicity to fish: In: Bioassay methods for acute toxicity Water Research, 3: (1975) $125-127$.

[29] Thompson, S.W. and Hunt R.D. Selected Histo-chemical and Histopathological methods. Spring field, Illinois U.S.A. (1966) pp 98-103.

[30] USEPA, Chlorpyrifos: Fate and risk assessment. United States Environmental Protection Agency. (1999).

[31] Van den Hevuel, M.R., Elis, R.J., Tremblay, L.A., Stuthridge, T.R., Exposure of reproductively maturing rainbow trout to a New Zealand pulp and paper mill effluent. Ecotoxicol. Environ. Saf. 51: (2002) 65-75.

[32] Visoottiviseth, P., Thamamaruitkun, T., Sahaphong, S., Riegrojpitak, S., Kruatrachue, M. Histopathological effects of triphen yltin hydroxide on liver, kidney and gill of Nile tilapia (Oreochromis niloticus). Applied Organometallic Chemistry. 13: (1999) 749-763.

[33] Zelikoff, J.T. Chapter 5: Fish Immunotoxicology. In Immunotoxicology and Immunopharmacology (eds. J.H. Dean, M.I. Luster, and A.E. Munson) Raven Press, New York. (1994) pp. 71-95. 